\title{
Regulation of insulin-like growth factor I binding in the rat uterus by growth hormone and thyroxine
}

\author{
C. Yallampalli, C. Osuamkpe and M. Nagamani \\ Department of Obstetrics and Gynecology, University of Texas Medical Branch, Galveston, \\ $T X 77550, U S A$
}

\begin{abstract}
Summary. The insulin-like growth factor-I (IGF-I)-binding sites in the rat uterus were characterized further and the effects of growth hormone and thyroxine examined. The ${ }^{125}$ l-labelled IGF-I binding sites on uterine membranes demonstrated relative binding affinity of less than $20 \%$ for IGF-II, less than $1 \%$ for insulin and no affinity for an unrelated peptide, epidermal growth factor, compared with $100 \%$ for IGF-I confirming the specificity of these binding sites. Scatchard analysis of the specific binding data revealed the presence of a single class of high-affinity binding sites $\left(K_{\mathrm{d}}=2.50 \pm 0.68 \mathrm{nmol}^{-1}\right.$, with a binding capacity of $1.02 \pm 0.13 \mathrm{pmol} \mathrm{mg}^{-1}$ membrane protein in the uterus of the pituitary-intact ovariectomized rat. After hypophysectomy, the uteri from these rats had significantly $(P<0.05)$ increased IGF-I binding sites, without significant changes in their affinity. Administration of growth hormone with or without L-thyroxine reversed this increase in IGF-I binding. Injection of thyroxine alone to the hypophysectomized ovariectomized rats had no significant effects on the uterine IGF-I binding sites. These data show that growth hormone, but not thyroxine, can regulate IGF-I binding sites in the rat uterus, possibly through regulating IGF-I production.
\end{abstract}

Kelwords: growth hormone; IGF-I binding; thyroxine: uterus; rat

\section{Introduction}

Insulin-like growth factors (IGFs) are a family of polypeptides with insulin-like and growthpromoting activity and they play major roles in mammalian development and growth (Froesch et al., 1985; Underwood et al., 1986). There are two molecular forms of IGF, IGF-I and IGF-II. IGF-I is found in plasma in concentrations of up to $1 \mu \mathrm{g} \mathrm{ml}^{-1}$ and is circulated bound to a large carrier protein. Although plasma IGF-I is traditionally considered to originate in the liver (Froesch et al., 1985), recent reports indicated that it is synthesized at multiple sites in the body (D'Ercole et al., 1984; Lund et al., 1986; Han et al., 1987), including the uterus (Murphy et al., 1987; Norstedt et al., 1989). Both oestradiol and growth hormone were demonstrated to increase IGF-I messenger ribonucleic acid (mRNA) in the uterus (Murphy \& Friesen, 1988).

Several lines of evidence also indicate that IGF-I receptors are distributed widely in various tissues (Ewton \& Florini, 1981; Bhaumick \& Bala, 1985; Adashi et al., 1988). Recently, IGF-I receptors have been demonstrated in the rat uterus (Chandrasekhar et al., 1990; Ghahary \& Murphy, 1989). The studies examining the endocrine requirement for optimal uterine decidualization indicated that both growth hormone and thyroxine were required in addition to oestradiol and progesterone (Kennedy \& Doktorcik, 1988). Thus, it is possible that growth hormone and thyroxine may regulate uterine IGF-I or IGF-I receptors in the uterus. Here, we examined the regulation of IGF-I receptors in the uterus by growth hormone and thyroxine. 


\section{Materials and Methods}

\section{Materials}

L-Thyroxine, oestradiol and progesterone were obtained from Sigma Chemical Co. (St Louis, MO). Ovine growth hormone (oGH, NIADDK-oGH-15) was a generous gift from the National Hormone and Pituitary Programs, National Institute of Diabetes, Digestive and Kidney diseases. Recombinant human IGF-I was purchased from Amgen Biologicals (Thousand Oaks, CA) and radioiodinated recombinant human IGF-I $2000 \mathrm{Ci} \mathrm{mmol}^{-1}$ was purchased from Amersham Co. (Arlington Heights. IL). All other chemicals used were of analytical reagent grade and were obtained from local sources.

\section{Animals and treatments}

Female Sprague-Dawley rats, hypophysectomized at $200-225 \mathrm{~g}$ body weight, were obtained from HarlanSprague-Dawley (Indianapolis, IN). Pituitary-intact female rats of the same strain were also obtained from the same supplier at $150-160 \mathrm{~g}$ body weight. The rats were housed under temperature- and light-controlled conditions (lights on from 05:00-19:00 h) with free access to food and water. The hypophysectomized rats were also given $2 \%$ glucose in addition to water.

From previous observations (Ghahary \& Murphy, 1989; Chandrasekhar et al., 1990) it was noted that ovarian steroids altered the uterine IGF-I receptor content and therefore all the rats used were ovariectomized. The rats were ovariectomized under ketamine anaesthesia (Ketalar: Parke-Davis, Morris Plains, NJ) and allowed at least 5 days to recover from surgery. At the start of the experiments, hypophysectomized ovariectomized rats had been hypophysectomized for 10-14 days. The rats then received s.c. injection of oGH $\left(120 \mu \mathrm{g}\right.$, twice in $0.03 \mathrm{~mol} \mathrm{NaHCO} 1^{-1}$ in $0.15 \mathrm{~mol} \mathrm{NaCl}^{-1}$, daily) and thyroxine $\left(1 \mu \mathrm{g}\right.$, in $0.15 \mathrm{~mol} \mathrm{NaCl} \mathrm{l}^{-1}$, daily). As controls, a group of pituitary-intact ovariectomized rats from the same colony received vehicle only. The treatments were continued for 3 days and four animals per group were killed by decapitation and exsanguination.

\section{Membrane preparation}

The uteri were rapidly removed, cleaned, weighed and placed in ice-cold buffer for at least $1 \mathrm{~min}$. The details of preparation of the membranes from the uterus have been described elsewhere (Chandrasekhar et al., 1990). Briefly, the uteri were cleaned and homogenized with three $15 \mathrm{~s}$ bursts at a setting of 60 in Tekmar Tissuemizer (Tekmar Co.,

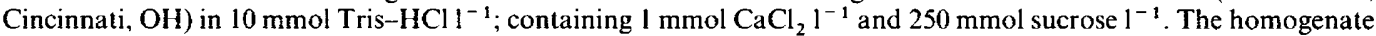
was then centrifuged at $700 \mathrm{~g}$ for $10 \mathrm{~min}$ and the supernatants were recentrifuged at $35000 \mathrm{~g}$ for $40 \mathrm{~min}$. The pellet was washed twice and resuspended in $10 \mathrm{mmol}$ Tris- $\mathrm{HCl}^{-1}$ containing $1 \mathrm{mmol} \mathrm{CaCl}_{2} 1^{-1}$. All the above procedures were carried out at $4^{\circ} \mathrm{C}$. The concentration of protein in the membrane preparations was determined by the method of Lowry et al. (1951), with bovine serum albumin as a standard.

\section{IGF-I binding assay}

Specific binding sites for IGF-I were measured on the uterine membrane preparations as described previously (Chandrasekhar et al., 1990). Briefly, two replicates of uterine membranes from each membrane preparation containing $50 \mu \mathrm{g}$ protein per tube were incubated with $0.02 \mathrm{nmol}{ }^{125} \mathrm{I}$-labelled IGF-I with or without various concentrations $(0.42-53 \mathrm{nM})$ of radioinert IGF-I in $200 \mu \mathrm{l} \mathrm{Tris}-\mathrm{HCl}$ with $0.1 \%$ gelatin. The optimal binding assay conditions in terms of time, temperature and $\mathrm{pH}$ were described previously (Chandrasekhar et al., 1990). The binding assays were performed by incubating the uterine membranes at $4^{\circ} \mathrm{C}$ for $20 \mathrm{~h}$ at $\mathrm{pH} 7.8$. At the end of the incubation, the membrane-bound ${ }^{125}$ I-labelled IGF-I was separated from free ${ }^{125}$ I-labelled IGF-I by centrifugation. The pelleted membrane-bound ${ }^{125}$ I-labelled IGF-I fraction was washed twice with $1 \mathrm{ml}$ of fresh ice-cold Tris-HCl buffer with $0 \cdot 1 \%$ gelatin and the bottom tips of the microfuge tubes were cut and counted for ${ }^{125} \mathrm{I}$ in a gamma counter (Packard Auto-gama, Downers Grove, IL, USA). Approximately $9.0 \%$ of the total counts added was specifically bound in the absence of radioinert IGF-I and $1.8 \%$ of the total counts added was nonspecifically bound in the presence of $53 \mathrm{~nm}$ radioinert IGF-I. The binding affinity and the total binding capacity of IGF-I for binding the uterine membranes were determined from a Scatchard plot of the specific binding data (Scatchard, 1949). The specificity of the binding of IGF-I to the uterine membranes was determined from a log-dose inhibition of specific binding of ${ }^{125}$ I-labelled IGF-I by radioinert IGF-I, IGF-II, insulin and epidermal growth factor (EGF), in terms of relative binding affinity as described for other receptors (Singh et al., 1985).

\section{Completeness of hypophysectomy}

At autopsy, the sella turcica of all hypophysectomized ovariectomized rats was examined for pituitary remnants which, if present, resulted in the exclusion of that animal from the study. 


\section{Data analysis}

Data from the binding assays were plotted according to the graphical representation of Scatchard (1949). Regression analysis was used to calculate line slopes and intercepts (Snedecor \& Cochran, 1967). The apparent dissociation constant $\left(K_{\mathrm{d}}\right)$ was calculated as the negative reciprocal of the slope and binding site concentration was determined from the $x$-axis intercept. The significance of treatment effects was determined by analysis of variance and when significant interactions were found, Duncan's new multiple range test (Steel \& Torrie, 1960) was used for comparisons between animal groups.

\section{Results}

\section{Specificity of ${ }^{125}$ I-labelled IGF-I binding}

To examine the specificity of the ${ }^{125} \mathrm{I}$-labelled IGF-I binding, we incubated uterine membranes obtained from pituitary-intact ovariectomized rats with $0.02 \mathrm{nmol}{ }^{125} \mathrm{I}$-labelled IGF-I $1^{-1}$, with or without various concentrations of radioinert ligands. ${ }^{125}$ I-labelled IGF-I binding to uterine membranes was displaced in a dose-dependent fashion by IGF-I, IGF-II and insulin (Fig. 1), but not by EGF. From the log-dose inhibition curves, the relative binding affinity of IGF-II and insulin was calculated to be $<20 \%$ and $<1 \%$ compared with that of IGF-I for displacing ${ }^{125}$ I-labelled IGF-I bound to the uterine membranes, respectively.

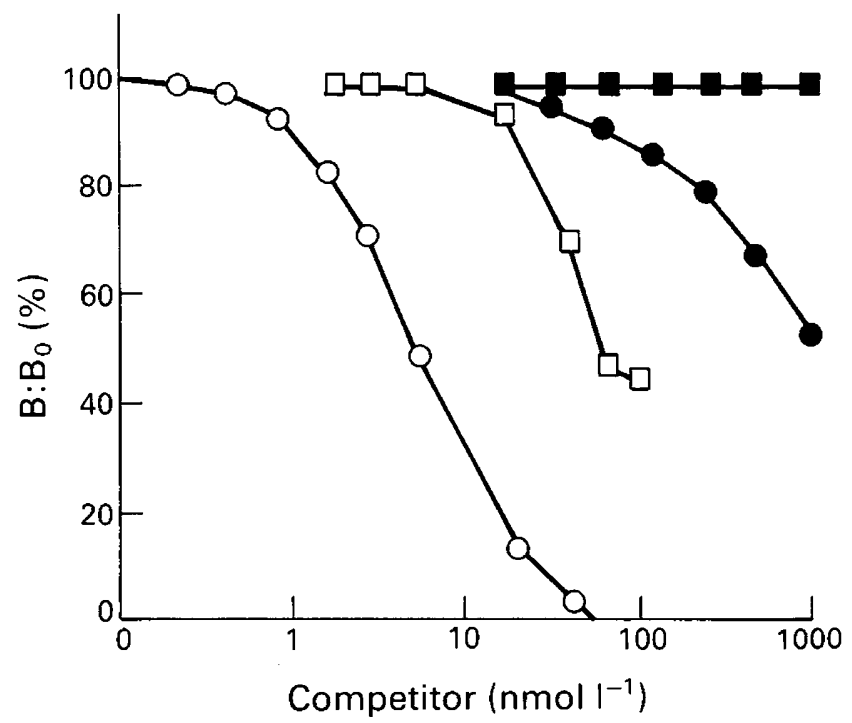

Fig. 1. Effect of insulin-like growth factor (IGF)-I (O), IGF-II ( $\square$ ), insulin ( $)$ and epidermal growth factor $(\boldsymbol{\square})$ on specific binding of ${ }^{125}$ I-labelled IGF-I to rat uterine membranes. Each value is a mean of triplicate determinations using pooled uterine membranes.

\section{Uterine weight}

Uterine wet weights from individual animals were determined and expressed as mean \pm SEM per group for each treatment. The weight of the uterus was $103 \cdot 7 \pm 9 \cdot 5,82 \cdot 3 \pm 8 \cdot 2,98 \cdot 0 \pm 5 \cdot 5,97 \cdot 7 \pm$ $6 \cdot 3,95.3 \pm 6.8 \mathrm{mg}$ in pituitary-intact ovariectomized and hypophysectomized ovariectomized rats receiving vehicle, growth hormone, growth hormone and thyroxine, or thyroxine, respectively, and was not significantly different from each other. 


\section{Uterine IGF-I receptors}

Scatchard plots of the specific binding data confirmed the presence of a single class of highaffinity binding sites for IGF-I on uterine membranes. The binding affinity calculated in terms of equilibrium dissociation constant, $K_{\mathrm{d}}$, and the number of specific binding sites for IGF-I on uterine membranes of pituitary-intact ovariectomized rats were $2.50 \pm 0.68 \mathrm{nmol}^{-1}$ and $1.02 \pm 0.13 \mathrm{pmol} \mathrm{mg}^{-1}$ protein, respectively (Table 1). The $K_{\mathrm{d}}$ values from Scatchard analysis of IGF-I specific binding data from hypophysectomized ovariectomized rats injected with vehicle, growth hormone, growth hormone + thyroxine or thyroxine are given in Table 1 . There were no significant differences in the $K_{\mathrm{d}}$ values among the treatment groups indicating that the affinity of the IGF-I binding to the uterus is not regulated by growth hormone or thyroxine. However, the concentration of specific IGF-I binding sites in the uterus are significantly $(P<0.05)$ higher in hypophysectomized ovariectomized rats compared with pituitary-intact ovariectomized rats (Table 1). The increase in concentration of IGF-I binding sites in the uterus of hypophysectomized ovariectomized animals was reversed by growth hormone, but not by thyroxine injection. The IGF-I binding sites were significantly $(P<0.05)$ higher in hypophysectomized ovariectomized rats receiving vehicle or thyroxine, compared with hypophysectomized ovariectomized rats receiving growth hormone with or without thyroxine and pituitary-intact ovariectomized rats. The difference in binding site concentrations among the last three groups was not significant.

Table 1. Specific binding of ${ }^{125}$ I-labelled IGF-I by uterine membrane preparations from hypophysectomized ovariectomized and pituitary-intact ovariectomized rats: summary of analysis of Scatchard plots

\begin{tabular}{|c|c|c|}
\hline Source of preparation & $\begin{array}{c}\text { Apparent dissociation } \\
\text { constant } \\
\left(\text { nmol } l^{-1}\right)\end{array}$ & $\begin{array}{c}\text { Binding site } \\
\text { concentration } \\
\text { (pmol } \mathrm{mg}^{-1} \text { protein) }\end{array}$ \\
\hline \multicolumn{3}{|c|}{ Hypophysectomized ovariectomized rats } \\
\hline Vehicle-treated & $4 \cdot 20 \pm 0.85$ & $2 \cdot 04 \pm 0 \cdot 08^{a}$ \\
\hline oGH-treated & $3.90 \pm 0.95$ & $1 \cdot 45 \pm 0 \cdot 20^{b}$ \\
\hline $\mathrm{oGH}+$ thyroxine-treated & $4.40 \pm 1.05$ & $1.44 \pm 0 \cdot 15^{b}$ \\
\hline Thyroxine-treated & $3.90 \pm 0.87$ & $2 \cdot 20 \pm 0.06^{\mathrm{a}}$ \\
\hline Ovariectomized rats & $2 \cdot 50 \pm 0 \cdot 68$ & $1.02 \pm 0.13^{b}$ \\
\hline
\end{tabular}

Means \pm s.e.m. with different superscripts differ significantly $(P<0 \cdot 05)$. Hypophysectomized ovariectomized rats received daily s.c. injections of $2 \times 120 \mu \mathrm{g}$ ovine growth hormone (oGH) with or without $1 \mu \mathrm{g}$ thyroxine or vehicle for only 3 days before being killed; ovariectomized rats received vehicle only. Each value represents the combined data obtained from two separate experiments.

\section{Discussion}

Specific binding sites for IGF-I have been demonstrated in a variety of tissues (Zapf et al., 1978; Rechler et al., 1980; Bhaumick et al., 1981; Adashi et al., 1988). The presence of IGF-I receptors in the rat uterus was previously reported (Chandrasekhar et al., 1990). The studies reported here further confirm the specificity of the IGF-I binding sites in the rat uterus since the relative binding affinity of radioinert IGF-II was $<20 \%$ compared with that of IGF-I for displacing ${ }^{125}$ I-labelled IGF-I bound to the uterine membranes. The relative binding affinity of $<20 \%$ and $<1 \%$ for IGF-II and insulin compared with that of $100 \%$ for IGF-I for displacing ${ }^{125}$ I-labelled IGF-I bound to the uterine membranes was similar to that reported for other tissues (Bhaumick \& Bala, 1985; Tramontano et al., 1987; Ritvos et al., 1988).

The effects of growth hormone and thyroxine on IGF-I receptors in the uterus were investigated. It was observed, for the first time, that the concentration of IGF-I receptors was increased (two-fold) 
in hypophysectomized ovariectomized rats compared with the pituitary-intact ovariectomized rats, suggesting that hormones from the pituitary gland are involved in the process. Hypophysectomized ovariectomized rats were, therefore, treated with growth hormone and thyroxine (a substitute for thyroid-stimulating hormone), since these hormones are required for normal uterine decidual cell reaction (Kennedy \& Doktorcik, 1988). The results of the experiment indicated that treatment with growth hormone with, or without, thyroxine reversed the increases in IGF-I binding sites in the uterus of hypophysectomized ovariectomized rats, such that the uterine IGF-I binding sites in these animals were similar to pituitary-intact ovariectomized rats. Thyroxine alone, however, had no significant effect on the uterine IGF-I binding sites in hypophysectomized ovariectomized rats. The effects of growth hormone on IGF-I binding sites appeared to be specific since growth hormone had no significant effect on the uterine wet weight in these animals.

The mechanism(s) by which growth hormone induces IGF-I receptor regulation in the uterus is not clear. It is possible that these changes in IGF-I binding in hypophysectomized ovariectomized rats may be due to direct effects of growth hormone on the cells bearing IGF-I receptors, since the receptor/binding protein activity for growth hormone has recently been reported in the rat uterus (Lobie et al., 1990). Alternatively, it is possible that the lack of growth hormone in hypophysectomized rats decreases IGF-I production (Reiter \& Lovinger, 1981; Bucher et al., 1983; Scott et al., 1985; Hynes et al., 1987) which, in turn, may result in increases in uterine IGF-I receptor concentration. Growth hormone administration to hypophysectomized animals has been demonstrated to induce elevations in immunoreactive-IGF-I concentrations (Roberts et al., 1986; Maiter et al., 1988; Daughaday \& Rotwein, 1989). Presumably, the increased IGF-I concentrations might have induced downregulation of uterine IGF-I binding sites. Ligand-induced downregulation of the receptors has been reported for IGF-I in IM-9 lymphocytes (Rosenfeld et al., 1982) and human skin fibroblasts (Rosenfeld \& Dollar, 1982). Scatchard analysis of the binding data suggested that the decreases in IGF-I binding sites by growth hormone was accounted for by a decrease in the number of binding sites rather than a change in binding affinity. In the studies by Rosenfeld et al. (1982), the ability of IGF-I, IGF-II and insulin to decrease the number of IGF-I receptors was proportional to their relative potency in inhibiting binding of ${ }^{125}$ I-labelled-IGF-I to IM-9 cells (IGF-I > IGF-II > insulin), suggesting that the downregulation depends upon receptor occupancy.

In summary, it has been confirmed that specific IGF-I receptors are present in the rat uterus and that these receptor concentrations are increased in hypophysectomized ovariectomized rats. Growth hormone, but not thyroxine alone, reversed this effect. The effects of growth hormone on IGF-I receptors of uterus may be mediated by IGF-I concentration and further studies are required to confirm this hypothesis.

These results were presented in part at the 32nd Annual Meeting of the Society for the Study of Reproduction on 15-18 July 1990, Knoxville, TN. This work was supported in part by Biomedical Research Support Grant to C. Yallampalli from the NIH through the University of Texas Medical Branch. We thank Rosemary Martinez for typing this manuscript.

\section{References}

Adashi, E.Y., Resnick, C.E., Hernandez, E.R., Svoboda, M.E. \& Van Wyk, J.J. (1988) In-vivo regulation of granulosa cell somatomedin-C/insulin-like growth factor I receptors. Endocrinology 122, 1383-1389.

Bhaumick, B. \& Bala, R.M. (1985) Ontogeny and characterization of basic somatomedin receptors in rat placenta. Endocrinology' 116, 492-498.

Bhaumick, B., Bala, R.M. \& Hollenberg, M.D. (1981) Somatomedin receptor of human placenta: solubilization, photolabelling, partial purification and comparison with insulin receptor. Proc. Natl Acad. Sci. USA 78, 4279-4283.

Bucher, H., Zapf, J., Torresani, T., Prader, A., Froesch, E.R. \& Illig, R. (1983) Insulin-like growth factors I and II, prolactin and insulin in 19 growth hormonedeficient children with excessive, normal or decreased longitudinal growth after operation for craniopharyngioma. New Engl. J. Med. 309, 1142-1146.

Chandrasekhar, Y., Narayan, S., Singh, P. \& Nagamani, M. (1990) Binding of insulin-like growth factor-I 
to rat uterus; variations during sensitization and decidualization. Acta Endocr. Copnh. 123, 243-250.

Daughaday, W.H. \& Rotwein, P. (1989) Insulin-like growth factors 1 and II. Peptide, messenger ribonucleic acid and gene structures, serum and tissue concentrations. Endocr. Rev. 10, 68-91.

D'Ercole, J., Stiles, A. \& Underwood, L.E. (1984) Tissue concentrations of somatomedin $\mathrm{C}$ : further evidence for multiple sites of synthesis and paracrine or autocrine mechanisms of action. Proc. Natl Acad. Sci. USA 81, 935-939.

Ewton, D.Z. \& Florini, J.R. (1981) Effects of somatomedins and insulin on myoblast differentiation in vitro. Devl Biol. 86, 31-39.

Froesch, E.R., Smid, Chr., Schwander, J. \& Zapf, J. (1985) Actions of insulin-like growth factors. A. Rev. Physiol. 47, 443-467.

Ghahary, A. \& Murphy, L.J. (1989) Uterine insulin-like growth factor-I receptors: regulation by estrogen and variation throughout the estrous cycle. Endocrinology 125, 597-604

Han, V.K.M., D'Ercole, A.J. \& Lund, P.K. (1987) Cellular localization of somatomedin (insulin-like growth factor) messenger RNA in the human fetus. Science 236, 193-197.

Hynes, M.A., Van Wyk, J.J., Brooks, P.J., D'Ercole, A.J., Jansen, M. \& Lund, P.K. (1987) Growth hormone dependence of somatomedin-C/insulin-like growth factor I and insulin-like growth factor II messenger ribonucleic acids. Mol. Endocr. 1, 233-242.

Kennedy, T.G. \& Doktorcik, P.E. ( 1988) Uterine decidualization in hypophysectomized-ovariectomized rats: effects of pituitary hormones. Biol. Reprod. 39, 318-328.

Lobie, P.E., Breipohl, W., Aragon, J.G. \& Waters, M.J. (1990) Cellular localization of the growth hormone receptor/binding protein in the male and female reproductive systems. Endocrinology 126, 2214-2221.

Lowry, O.H., Rosebrough, N.J., Farr, A.L. \& Randall, R.J. (1951) Protein measurement with the folin phenol reagent. J. Biol. Chem. 193, 265-275.

Lund, P.K., Moats-Staats, B.M., Hynes, M.A., Simmons, J.G., Jansen, M., D'Ercole, A.J. \& Van Wyk, J.J. (1986) Somatomedin-C/insulin-like growth factor-I and insulin-like growth factor-1I mRNAs in rat fetal and adult tissue. J. Biol. Chem. 261, 14539 i 4544.

Maiter, D., Underwood, L.E., Maes, M., Davenport, M.L. \& Ketelslegers, J.M. (1988) Different effects of intermittent and continuous growth hormone (GH) administration on serum somatomedin-C/insulin-like growth factor I and liver GH receptors in hypophysectomized rats. Endocrinology 123, 1053-1059.

Murphy, L.J. \& Friesen, H.G. (1988) Differential effects of estrogen and growth hormone on uterine and hepatic insulin-like growth factor I gene expression in the ovariectomized hypophysectomized rat. Endocrinology 122, 325-332.

Murphy, L.J., Murphy, L.C. \& Friesen, H.G. (1987) Estrogen induces insulin-like growth factor I expression in the rat uterus. Mol. Endocr. 1, 445-450.

Norstedt, G., Levinovitz, A. \& Eriksson, H. (1989) Regulation of uterine insulin-like growth factor I
mRNA and insulin-like growth factor II mRNA by estrogen in the rat. Acta Endocr. 120, 466-472.

Rechler, M.M., Zapf, J., Nissley, S.P., Podskalny, J.M., Schilling, E.E. \& Humbel, R.E. (1980) Interactions of insulin-like growth factors I and II and multiplication-stimulating activity with receptors and serum proteins. Endocrinology 107, 1451-1459.

Reiter, E.O. \& Lovinger, R.D. (1981) The use of a commercially available somatomedin-C radioimmunoassay in patients with disorders of growth. $J$. Pediatr. 99, 720-724.

Ritvos, O., Rutanen, E.M., Pekonen, F., Jalkanen, J., Suikkari, A.-M. \& Ranta, T. (1988) Characterization of functional type I insulin-like growth factor receptors from human choriocarcinoma cells. Endocrinology 122, 39540 l.

Roberts, C.T., Brown, A.L., Graham, D.E., Seelig, S., Berry, S., Gabbay, K.H. \& Rechler, M.M. (1986) Growth hormone regulates the abundance of insulinlike growth factor I RNA in adult rat liver. J. Biol. Chem. 261, 10025-10028.

Rosenfeld, R.G. \& Dollar, L.A. (1982) Characterization of the somatomedin-C/insulin-like growth factor I (SM-C/IGF-I) receptor on cultured human fibroblast monolayers: regulation of receptor concentrations by SM-C/IGF-I and insulin. J. Clin. Endocr. Metab. 55, 434-440.

Rosenfeld, R.G., Hintz, R.L. \& Dollar, L.A. (1982) Insulin-induced loss of an insulin-like growth factor-I receptor on IM-9 lymphocytes. Diabetes 31, 375-381.

Scatchard, G. (1949) The attractions of proteins for small molecules and ions. Ann. NY Acad. Sci. USA 51, $660-672$.

Scott, C.D., Martin, J.L. \& Baxter, R.C. (1985) Production of insulin-like growth factor $I$ and its binding protein by adult rat hepatocytes in primary culture. Endocrinology 116, 1094-1101.

Singh, P., Rae-Venter, B., Townsend, C.M., Jr, Khalil, T. \& Thompson, J.C. (1985) Gastrin receptors in normal and malignant gastrointestinal mucosa. Ageassociated changes in gastrin receptors. Am. $J$. Physiol. 249, G761-G769.

Snedecor, G.W. \& Cochran, W.G. (1967) Statistical Methods. Iowa State University Press, Ames.

Steel, R.G.D. \& Torrie, J.H. (1960) Principles and Procedures of Statistics, pp. 107-109. McGraw Hill, New York.

Tramontano, O., Moses, A.C., Picone, R. \& Ingbar, S.H. (1987) Characterization of the receptor for insulinlike growth factor 1 in the FRTL-5 rat thyroid follicular cell line. Endocrinology 120, 785-790.

Underwood, L.E., D'Ercole, A.J., Clemmons, D.R. \& Van Wyk, J.J. (1986) Paracrine functions of somatomedins. J. Clin. Endocr. Metab. 15, 59-77.

Zapf, J., Schoenle, U. \& Froesch, E.R. (1978) Insulin-like growth factors 1 and II: Some biological actions and receptor binding characteristics of two purified constituents on nonsuppressible insulin-like activity of human serum. Eur. J. Biochem. 87, 285-296.

Received 2 January 1991 